\title{
Foraminiferal zonation of the Danish Oligocene sediments
}

\author{
KAARE ULLEBERG
}

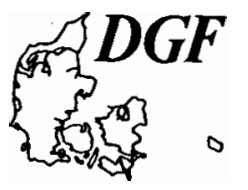

\begin{abstract}
Ulleberg, K.: Foraminiferal zonation of the Danish Oligocene sediments. Bull. geol. Soc. Denmark, Vol. 36, pp. 191-202, Copenhagen, December, 31st, 1987. https://doi.org/10.37570/bgsd-1988-36-02

The foraminiferal fauna of the onshore Danish area is presented. Stratigraphically, four biozones are established, i.e. the Middle Oligocene Turrilina alsatica zone and Globigerina zone and the Late Oligocene Asterigerina gürichi gürichi zone and Angulogerina gracilis zone. The regional distribution of these units in the Danish Embayment north of the Ringkøbing-Fyn High is discussed.
\end{abstract}

Kaare Ulleberg, Kløverstien 7, N-3073 Galleberg, Norway. September 25th, 1985.

\section{Introduction}

The foraminifera in Danish Oligocene deposits have been described by Larsen \& Dinesen (1959), Kristoffersen (1965), Ulleberg (1971), Ulleberg (1974), Christensen \& Ulleberg (1973 \& 1974), Dam (1976), and Meyer (1981). All These works deal more or less with investigations of single localities. It is the intention of the present paper to give a regional stratigraphic description of the Danish Oligocene Basin based on Foraminifera. Figure 1 indicates the localities examined in this paper.

Even though this study is not finished, there is enough data to establish a biostratigraphic model, and to present the regional distribution of the zones. The study is mainly based on benthonic foraminifera. Only genera remarks on the planktonic part of the fauna are given.

\section{Methods}

Standard micropaleontological laboratory treatment has been used (Feyling-Hanssen 1958, Hiltermann 1958). Usually 50 to $100 \mathrm{~g}$ of dried material from each sample were processed. The sediment was soaked and disintegrated in $3-5 \% \mathrm{H}_{2} \mathrm{O}_{2}$ and washed through sieves with mesh diameters $0.07,0.1$ and $1.0 \mathrm{~mm}$. Fractions greater than 0.1 $\mathrm{mm}$ were analysed.

\section{The foraminiferal fauna}

In general, the Oligocene marine deposits in the Danish basin are rich in foraminifera. Usually 300 to 10,000 specimens occur in $100 \mathrm{~g}$ of dried sediment. The fauna is dominated by calcareous benthonic foraminifera. Planktonic tests are usually rare; they are only frequent in one particular stratigraphic zone, but they may occur commonly in other zones. Agglutinated foraminifera seldom exceed $1 \%$ of the fauna.

The foraminiferal fauna throughout the Danish Oligocene sequence is divided into four distinct biozones which are from base to top: Turrilina alsatica zone, Gobigerina zone, Asterigerina gürichi gürichi zone, and Angulogerina gracilis zone. The zones correspond to the lithological formations: Viborg Formation, Hvorslev Clay formation, Branden Formation and the Vejle Fjord Formation/Sofienlund Formation. The Hvorslev Clay formation is not yet defined. It is seen as a distinct glauconitic clay-layer in Viborg 1 Deepbore, from $169,5 \mathrm{~m}$ to $164,5 \mathrm{~m}$. Lieberkind (1977, fig. 12) has shown this formation as a "Glauconitic clay" above the Viborg Clay Formation.

The most complete section through the four biozones is seen in the Viborg 1 Deep-bore. The Viborg 1 Deep-bore stands out as a model, and is used as a reference section in this presentation (fig. 1). 


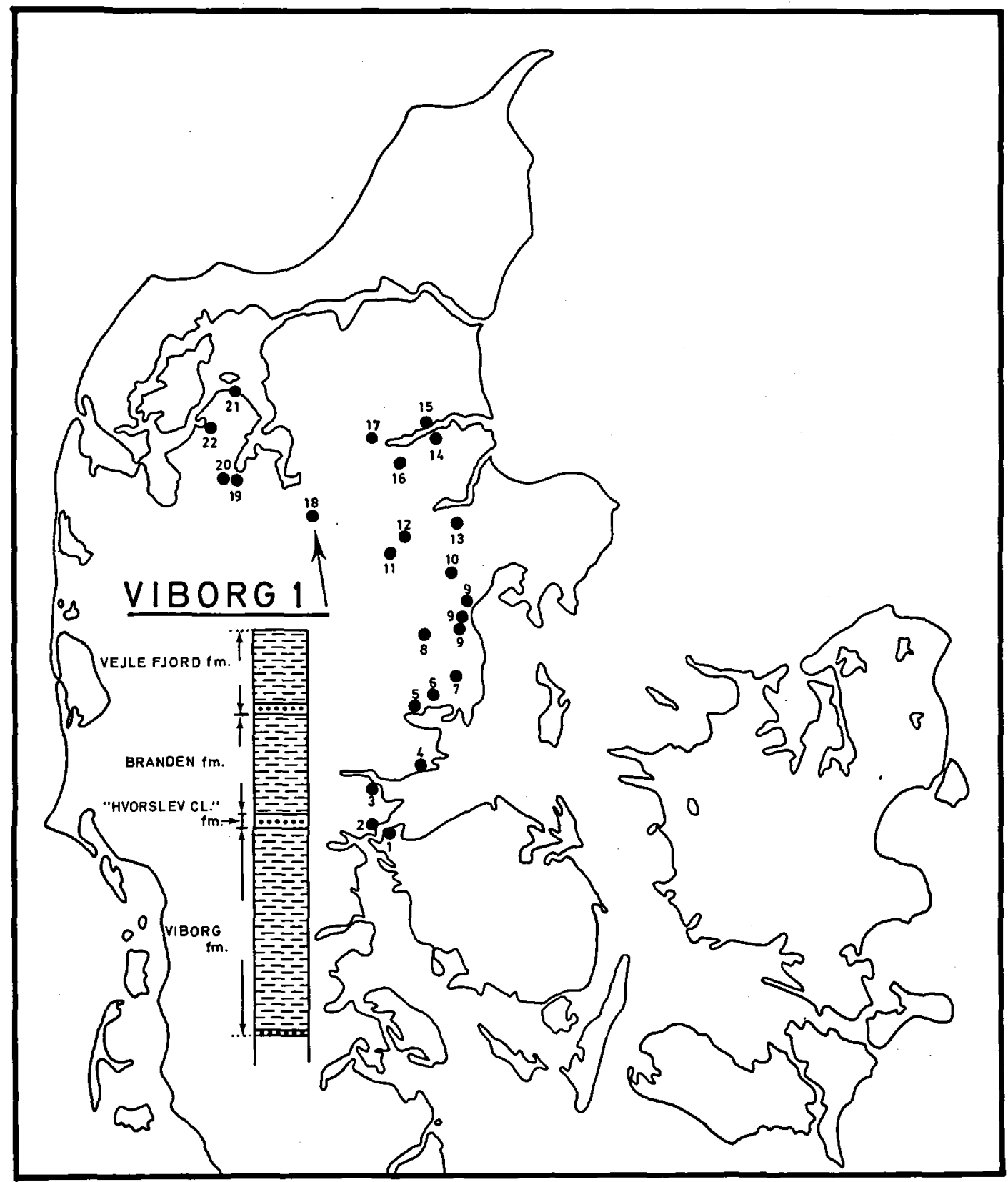

Fig. 1. Geographical location of Oligocene outcrops used in this study; 1. Røjle Klint, 2. Fredericia area, 3. Skansebakken, Brejning, 4. Albækhoved, 5. Stensballe, 6. Aas, 7. Rodstenseje, 8. Boring NW of Skanderborg, 9. Aarhus area, 10. Grundfør, 11. Hvorslev clay pit, 12. Sofienlund, 13. Ølst, 14. Cilleborg, 15. Skovbos nye grav, 16. Fårup, 17. Hobro well No. 1, 18. Viborg 1 Deep-bore, 19. Skive area, 20. Hesselbjerg, 21. Branden, 22. Harre Deep-bore.

The Turrilina alsatica zone (fig. 2, plate 1):

The Turrilina alsatica zone was originally described by Christensen \& Ulleberg (1973) from the Sofienlund locality. General remarks on the fauna in the Danish Embayment are given by Christensen \& Ulleberg (1974), whereas a more detailed description on the fauna in the Sofienlund locality was given by Ulleberg (1974).

The most complete development of the zone is 


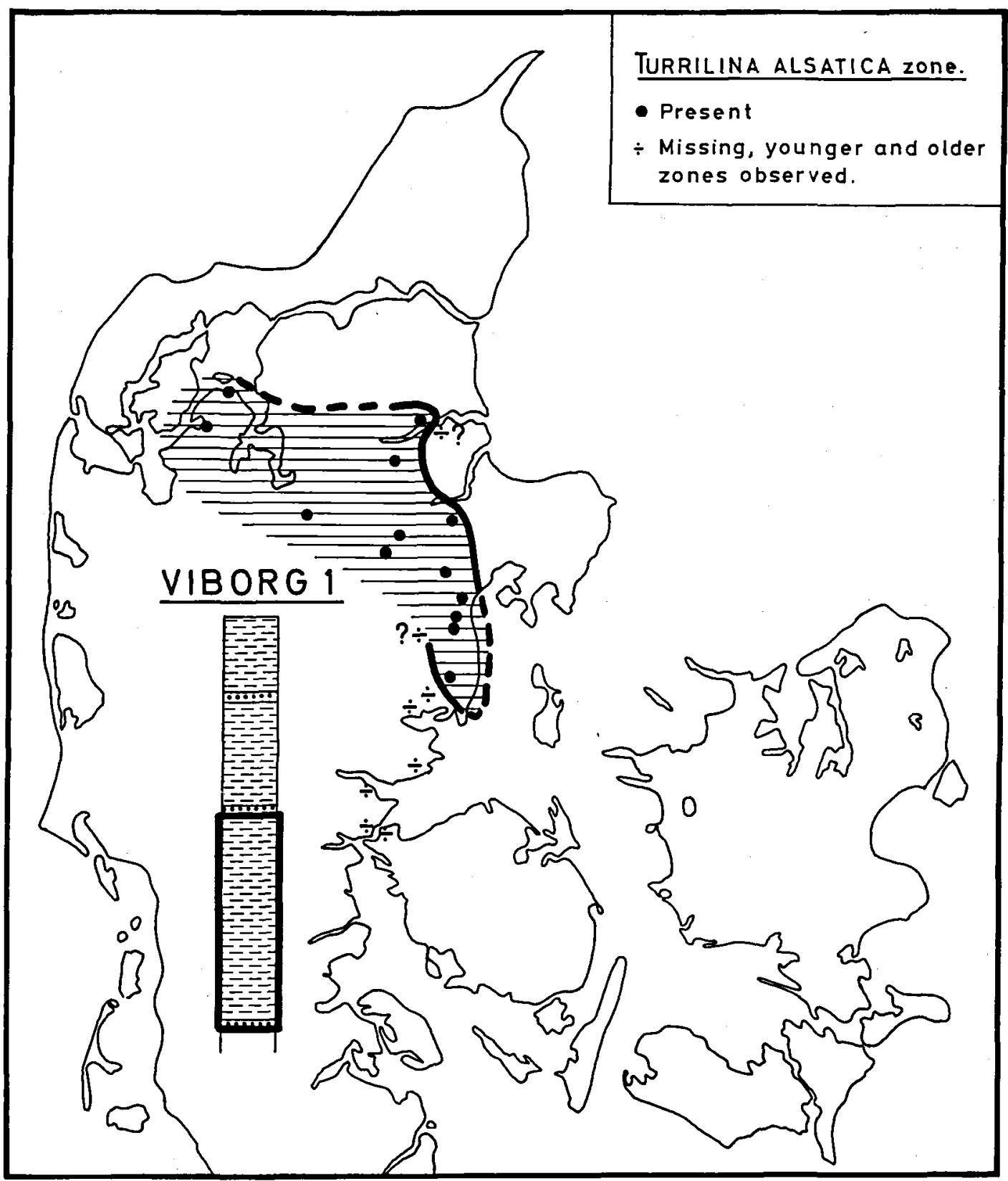

Fig. 2. Turrilina alsatica zone. Geographical distribution in onshore Denmark.

today probably restricted to the central part of the Danish Oligocene Basin, as registered in Viborg 1 Deep-bore between $255,3 \mathrm{~m}$ and $169,5 \mathrm{~m}$ below surface. The upper 10 to $15 \mathrm{~m}$ contain very few foraminifera. This is assumed to reflect dissolution of calcareous material, since a few strongly pyritized or partly dissolved and fragmented tests have been observed. The silty sediment in this interval may support this assumption. It is assumed that this more or less unfossiliferous part also belongs to the Turrilina alsatica zone, as the few specimens recorded clearly indicate similarities to the fossiliferous part below.

The Turrilina alsatica zone is characterizes by 


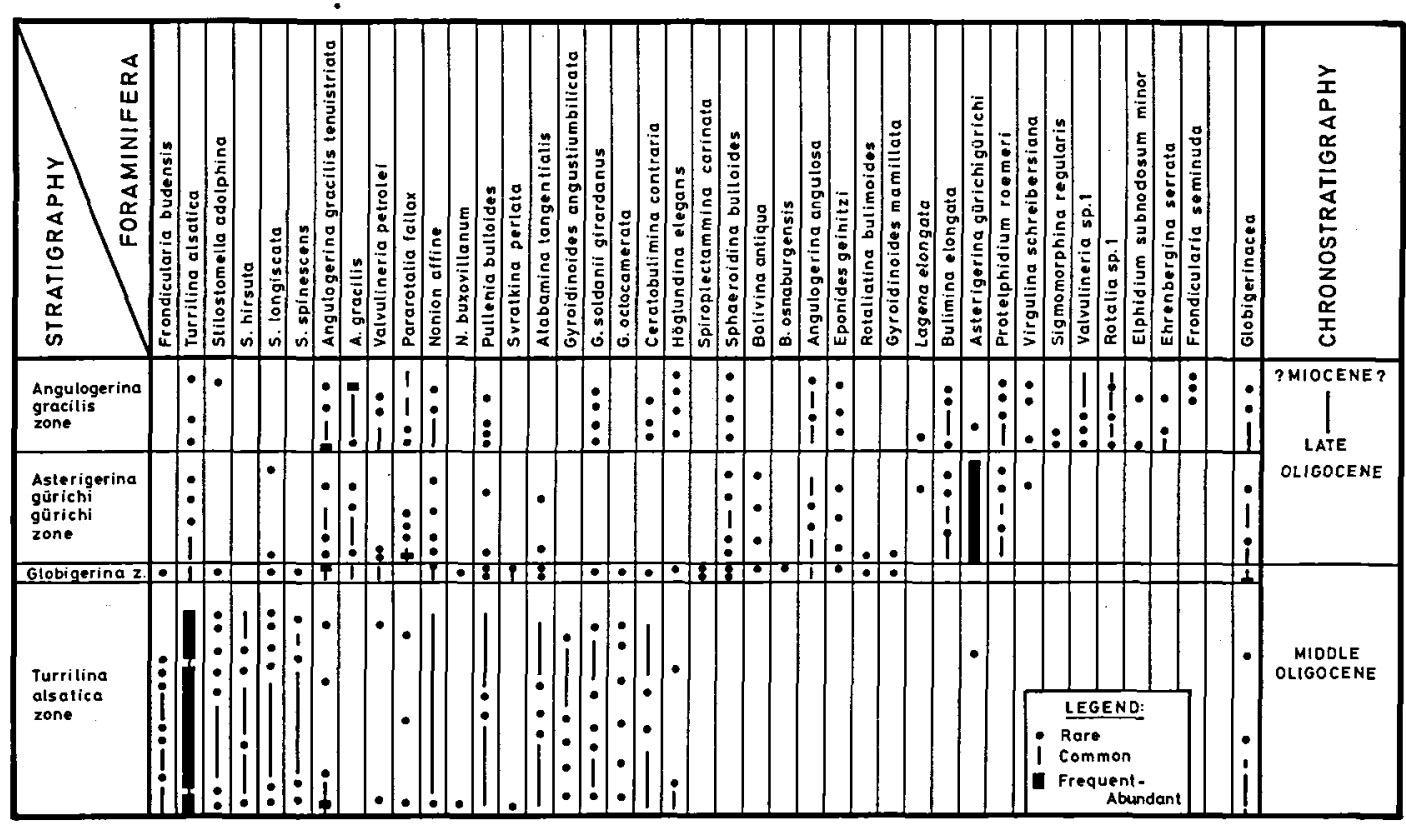

Plate 1. Simplified foraminiferal range chart of Oligocene sediments in Denmark.

an extreme high content of Turrilina alsatica, usually between $30 \%$ and $60 \%$, but varying from $10 \%$ to approximately $90 \%$. Nonion affine and Pullenia bulloides are also frequent and the three species together constitute at least $40 \%$ of the fauna.

A faunal description and a faunal list from the Sofienlund locality are given by Christensen \& Ulleberg (1973) and Ulleberg (1974). As the species composition is nearly constant, these works give a general description of the Turrilina alsatica zone throughout the Danish Basin.

In spite of the more or less uniformity of species composition of the fauna throughout the zone, minor vertical variations have been observed. These may provide a base for separation into zonules. Here, only a few remarks on these minor stratigraphic variations are given. Species such as Svratkina perlata, Valvulineria petrolei, Karreria steegeri, and Nonion buxovillanum seem to be more or less restricted to the basal part of the Turrilina alsatica zone. Angulogerina gracilis tenuistriata and Höglundina elegans are also more frequent here than in the rest of the zone. The species are thought to represent a shallow marine transgressive phase of the "Viborg sea". This zonule is assumed to include the lithological units of the Grundfør clay and the lower part of the Viborg clay. No foraminiferal boundary has been observed between the Grundf $\varnothing \mathrm{r}$ clay and the Viborg clay. A gradual change in fauna occurs across this lithological boundary and continues into the Viborg clay, indicating a gradual transgressive phase probably with increasing depth combined with more open marine environments. Christensen \& Ulleberg (1974) mentioned a gradual increase of planktonic specimens to about $15 \mathrm{~m}$ above the base of the Viborg Formation in the Viborg 1 Deep-bore. A similar increase in the nannoplankton content was observed by Mikkelsen (1975).

Other significant species in the Turrilina alsatica zone are species of Nodosaria, Dentalina, and Stilostomella (Ulleberg 1974).

The planktonic elements of the Turrilina alsatica zone, consist mainly of rare specimens of the so-called "Globigerina ex. gr. bulloides", consisting of Globigerina officinalis and subspecies of G. praebulloides and G. ouachitaensis. Significant among the other rare planktonic specimens are Turborotalia cf rugosoaculeata and Globigerina cf danvillensis. Specimens of $G$. cf danvillensis in the Viborg Formation are very similar to those described by Marks \& Vessem (1971) from the Silberberg Formation in Germany.

The age of the fauna, based on the benthonic 
tests, is Middle Oligocene since it is probably comparable with Rupel 2 in Northern Germany, according to Spiegler's (1965) zonation (Christensen \& Ulleberg 1973), and parts of zone FF (Dooppert \& Neele 1983) in the Netherlands. However, Mikkelsen (1975) refers most of the Turrilina alsatica sequence in the Viborg 1 Deepbore to the Early Oligocene, based on the nannoplankton content.

The paleoenvironment is assumed to be like that of a present day shelf area (Christensen \& Ulleberg 1973).

The regional distribution of the Turrilina alsatica zone is restricted to the distribution of the Viborg Formation, i.e. the central part of the Danish basin, north of the Ringkøbing-Fyn high (fig. 2). From this central part of the basin, the zone extends northwards in the Branden locality, where it occurs below a $20 \mathrm{~m}$ thick section of Branden Clay Formation. The zone has not yet been observed to the West probably because of heavy glacial erosion during the Quarternary. In Central and East Jutland, the zone has been observed at several localities. It is present as far North as Mariager Fjord, where it has been observed in the "Skovbos nye grav" on the northern side of the fjord. Probably, the Zone may also be present in the Hobro well no 1. According to Dinesen (pers. com.) specimens of Ceratobulimina contraria, Gyroidina spp., Frondicularia budensis, Turrilina alsatica, and Epistomina elegans may be caved from a thin section of Turrilina alsatica zone above in the well.

To the South, the zone occurs in Ølst, South of Randers, in Sofienlund and Hvorslev (around the village Ulstrup), in Grundfør and in the subsurface of Aarhus City. Farther South, it occurs around the town of Odder, in Rodstenseje and seems to wedge out between Horsens Fjord and Sams $\emptyset$, since only older and younger zones occur South of this area.

\section{The Globigerina zone (fig. 3, plate 1):}

The glauconitic clay layer above the Viborg Formation in the Viborg 1 Deep-bore, from $169,5 \mathrm{~m}$ to $164,5 \mathrm{~m}$ below surface, and in the Hvorslev locality, 1-2 $\mathrm{m}$ thick, has a distinct foraminiferal fauna characterized by a strong influx of planktonic tests, particularly in its lowermost part, gradually decreasing to zero in the uppermost part. This is a very remarkable feature, as planktonic specimens are usually rare in Danish Oligocene sediments.

Up to now, no characteristic forms have been observed. Species of the Globigerina ex. gr. bulloides seem to be the most common forms.

The benthonic assemblage of this zone is also characteristic and clearly distinct from the biozones below and above. It is dominated by calcareous specimens; very few agglutinated tests are found. The assemblage is characterized by the disappearance or decrease in frequency of the species frequently occurring in the Turrilina alsatica zone; the distinct representation of Turrilina alsatica itself decreases to a few percentage of the fauna. The marked presence of uniserial tests (Nodosaria, Dentalina, Stilostomella) also decreases to almost zero. Angulogerina gracilis subsp. with variated wallornamentation is common. Other diagnostic species are: Valvulineria petrolei, Svratkina perlata, Eponides geinitzi, Bolivina antiqua, Rotaliatina bulimoides, Gyroidinoides mamillata, and Sphaeroidina bulloides, which all occur in the Globigerina zone and younger zones; Spiroplectammina carinata and Bolivina osnaburgensis seem to be restricted to this zone. Several of the above-mentioned forms seem to be restricted to Middle Oligocene deposits in NW Europe. Therefore, the Globigerina zone is assumed to be of Middle Oligocene age.

Up to now, this zone has been observed only in three localities, Viborg 1 Deep-bore, Hvorslev locality and the Harre Deep-bore. It is missing in several localities, where older and younger zones are present (fig. 3).

Even if there are faunal variations between the Globigerina zone in the Viborg 1 Deep-bore and the two other localities, the general faunal composition clearly separates the zone from the zones below and above in all localities (plate 1). Therefore, it is assumed that the Globigerina zone is a true stratigraphic unit occurring centrally in the Danish Oligocene Basin. The stratigraphic position in the localities and the faunal content do not give any indications that the zone may represent a facies equivalent to one of the other foraminiferal zones. The stratigraphical position of the Globigerina zone suggests a short open marine phase in the Danish Oligocene sea where oceanic water was brought into the area. The extreme high representation of planktonic 


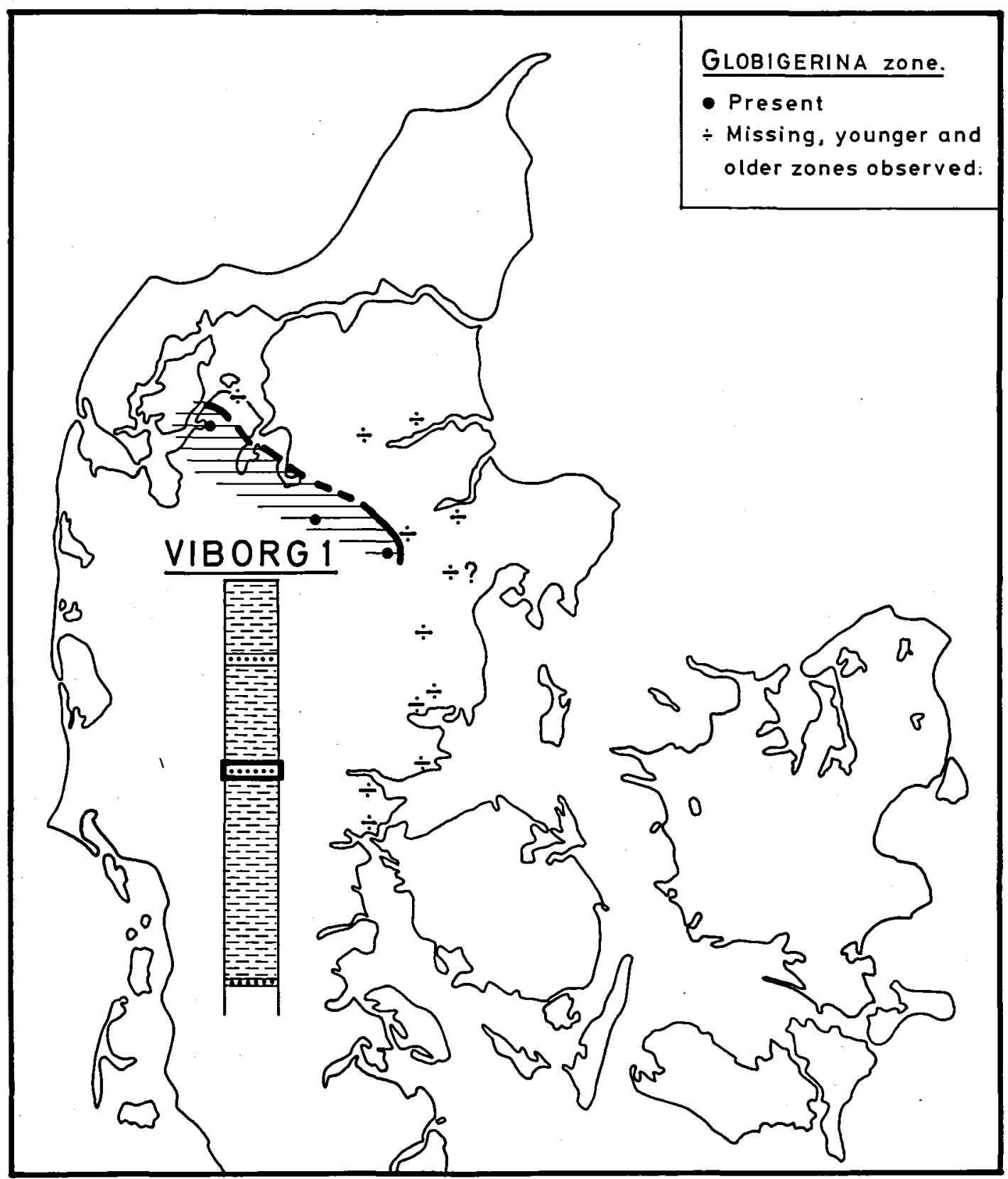

Fig. 3. Globigerina zone. Geographical distribution in onshore Denmark.

tests indicates that open marine influx existed in the lower part of the zone.

The Asterigerina gürichi gürichi zone (fig. 4 , plate 1 ):

An abrupt change occurs in the fauna when the boundary between the glauconitic clay of the Globigerina zone to the clay section above in the Viborg 1 Deep-bore is crossed. A new fauna appears and stays more or less constant throughout this clay unit, from $164,5 \mathrm{~m}$ to $123 \mathrm{~m}$ below surface. Characteristic is the abrupt appearance and dominance of Asterigerina gürichi gürichi, 


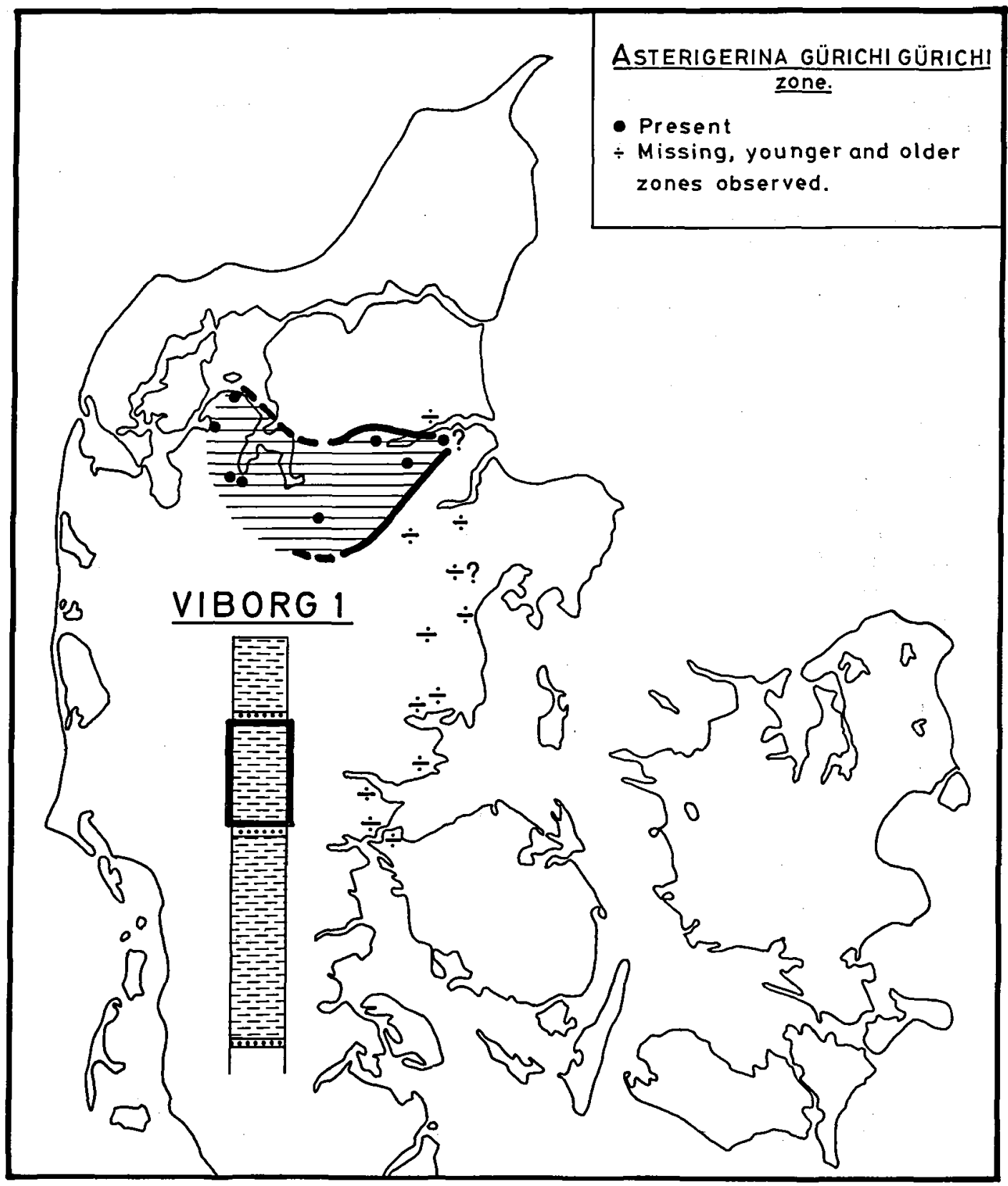

Fig. 4. Asterigerina gürichi gürichi zone. Geographical distribution in onshore Denmark.

which often has been referred to as marking the "Asterigerina gürichi transgression". The species makes up more than $50 \%$ and often up to $90 \%$ of the fauna. Since only a few single specimens of Asterigerina gürichi gürichi have been observed in the zones above and below, this dominance is biostratigraphically very significant.
The zone is more or less fossiliferous throughout the clay sequence in the Viborg 1 Deep-bore. But here, and at other localities, non-fossiliferous parts of the zone may occur. This is assumed to be of local character and has probably no stratigraphic significance in the basin. Even if the fauna in general is rich in number of specimens, 
this zone has the lowest faunal diversity of all Oligocene biozones, as a result of the constant high dominance of Asterigerina gürichi gürichi. Seldom more than 60 different species occur in a sample and most of them are represented only by few specimens. The fauna consits almost exclusively of calcareous tests; benthonic specimens usually dominate, although planktonic forms may be locally abundant. Most of these may be referred to Globigerina ex. gr. bulloides.

The benthonic tests comprise mainly species which have their first appearance at the base of this zone or in the Globigerina zone below, although some species from the Turrilina alsatica zone do occur. Among the more significant species, i.e. represented in all the samples, are: $A n$ gulogerina gracillis, Angulogerina gracillis tenuistriata, Angulogerina angulosa, Bulimina elongata, Protelphidium roemeri, Sphaeroidina bulloides, and Pararotalia fallax.

The Asterigerina gürichi gürichi zone is referred to the Late Oligocene. The characteristic dominance of Asterigerina gürichi gürichi is observed in many parts of NW Europe and referred to the interval about or immediately above the Middle/Upper Oligocene boundary (Dam \& Reinhold, 1942; Batjes, 1958; Bettenstaedt et al., 1962; Kümmerle, 1963; Indans, 1965). As the major part of the accessory species of the fauna are more common in younger than in older deposits, the present writer prefers to refer the zone, at this stage of investigation, to the Late Oligocene rather than to the Middle Oligocene.

The regional distribution of the Asterigerina gürichi gürichi zone in the Danish area seems to be restricted to the central part of the Danish Embayment in Jutland (fig. 4). Outside the Viborg 1 Deep-bore, the zone occurs in outcrops around the city of Skive and northwards to the Branden clay pit, where it is probably restricted to the type section of the Branden Clay. Farther towards the West, the zone has only been observed in the Harre Deep-bore. It is not found in any outcrops, probably because of Quaternary glacial erosion. To the north east, the zone is observed as far as Fårup north of the city of Randers. Whether the zone is present in the classical Oligocene area around Mariager Fjord may be questioned. Until now, only older and younger Oligocene foraminiferal zones have been observed there. However, Troelsen (1955) made taxonomic studies on 99 specimens of Asterigerina gürichi gürichi from the type locality of Cilleborg Clay in that particular area. The material used was taken from the Geological Museum of Copenhagen. In the writer's opinion the presence of so many specimens of Asterigerina gürichi gürichi indicates the presence of the zone there because such high numbers of specimens do not occur in other zones. Today, unfortunately the Cilleborg clay pit is completely overgrown. Field work in this area has not yet revealed any Oligocene deposits. On the northern side of the fjord, in the "Skovbos nye grav", the Turrilina alsatica zone is overlain by the Angulogerina gracilis zone. The Asterigerina gürichi gürichi zone is so far not represented in that area. However, the foraminifera of the Asterigerina gürichi gürichi zone were observed by Dinesen in the Hobro well no 1 (Dinesen, pers.com.). The samples examined represent ditch cuttings, so the thickness of the zone is very difficult to estimate, probably about $10 \mathrm{~m}$. However, Dinesen indicates that these beds may be a flou in the Pleistocene deposits.

The Angulogerina gracillis zone (fig. 5, plate 1):

The youngest zone in the Oligocene sequence of Denmark is referred to as the Angulogerina gracilis zone. In the Viborg 1 Deep-bore, it coincides with the uppermost glauconitic clay sequence and the overlying dark micaceous clay section from $123 \mathrm{~m}$ to $90 \mathrm{~m}$ below surface. This sequence is overlain by Quaternary deposits. The zone was described from the Sofienlund locality by Christensen \& Ulleberg (1973), who referred the index species to the genus $U$ vigerina. On account of the distinct triangular cross-section of specimens without flattened sides (as in Trifarina), the species is here referred to the genus Angulogerina; and the name of the zone is hereby changed from Uvigerina gracilis zone to Angulogerina gracilis zone. Larsen \& Dinesen (1959) also described the zone.

The name of the zone reflects the dominant occurrence of Angulogerina gracilis. Different subspecies occur and are recognised according to the variation in the ornamentation of the test surface. Ribbed ornamented tests, referred to $A n$ gulogerina gracilis tenuistriata, are most frequent especially in the lower part of the zone and grad- 


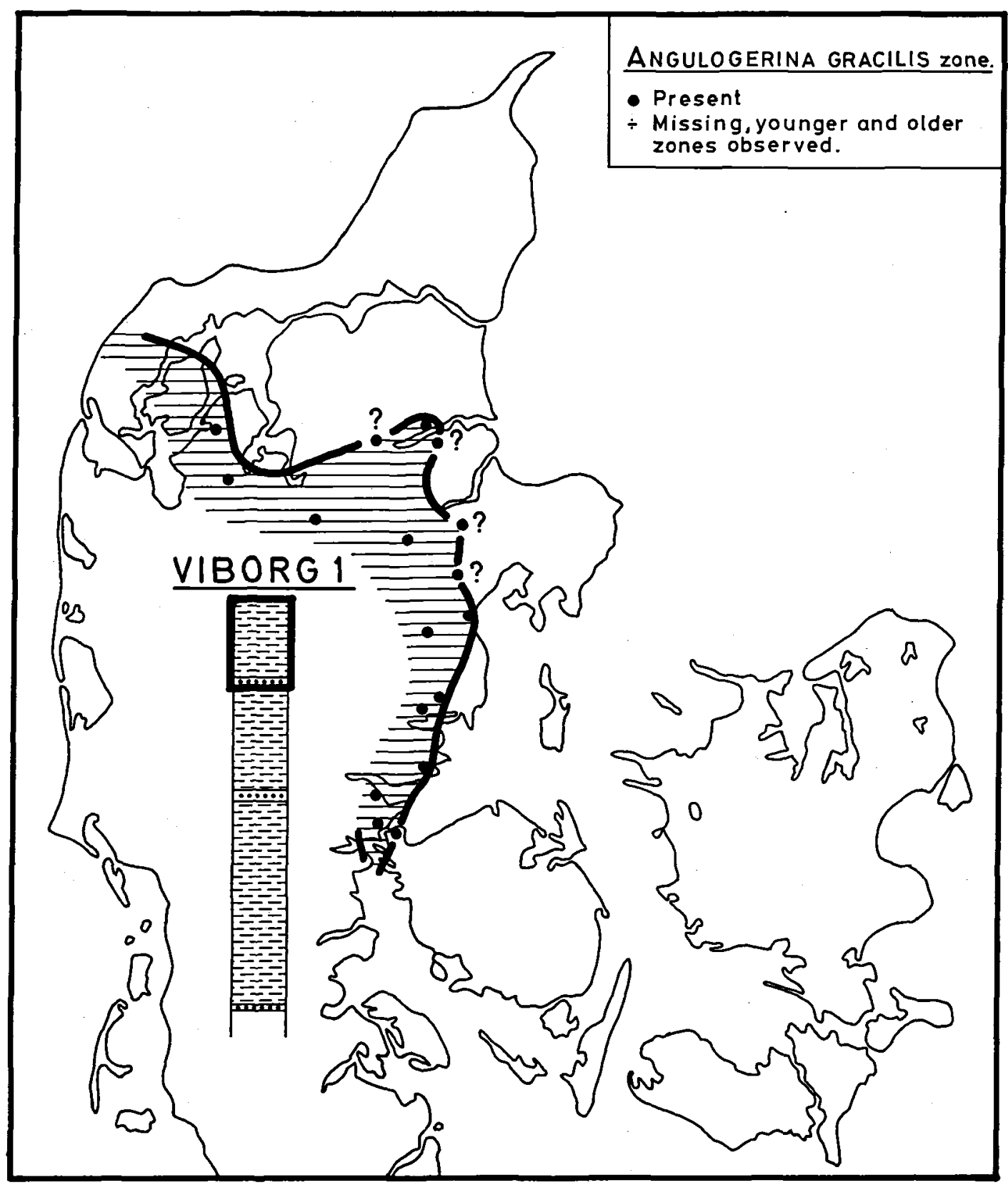

Fig. 5. Angulogerina gracilis zone. Geographical distribution in onshore Denmark.

ually decreasing in frequency upwards. On the other hand, smooth tests, referred to Angulogerina gracilis, are rare in the lower part and increase upwards. This variation was also observed by Larsen \& Dinesen (1959). In between, jagged to hispid ornamented tests also occur.

The zone varies from highly fossiliferous to non-fossiliferous throughout the section in the Viborg 1 Deep bore. This is probably due to secondary dissolution, as strongly weathered faunas also accur. In other localities, the zone is fossiliferous throughout the section.

In well preserved material, the non-weathered fauna is rich in number of species and specimens. 
Approximately 5000 specimens per $100 \mathrm{~g}$ dried material, and about 100 species per sample is estimated.

Next to Angulogerina gracilis complex, the following species are diagnostic: Bulimina elongata, a Pararotalia fallax complex, Sphaeroidina bulloides, Protelphidium roemeri, Valvulineria complanata, and Virgulina schreibersiana. The two last mentioned species do not occur in older zones. Ehrenbergina serrata, Lagena elongata, Sigmomorphina regularis, Elphidium subnodosum minor have their first appearance at the base of the zone, whereas Frondicularia seminuda seems to occur higher up in the zone. The total absence of Asterigerina gürichi gürichi is also characteristic; only a few scattered specimens have been observed.

The zone is referred to the Late Oligocene because the fauna shows some continuation of the fauna in the zone below. Furthermore, the two species Elphidium subnodosum minor and Turrilina alsatica seems to be restricted to pre-Miocene deposits in NW-Europe. An Oligocene age is confirmed by molluscs (Ravn, 1907; Harder, 1913; Eriksen, 1937).

The stratigraphic relationship with the fauna of the Klintinghoved Formation, which is probably the marine lithostratigraphic unit above the $A n$ gulogerina gracilis zone, is uncertain. Unfortunately, the Angulogerina gracilis zone in the Viborg 1 Deep-bore, is overlain by Quaternary deposits. Until now, no marine sequence of continuous marine Upper Oligocene - Lower Miocene deposits has been found in Danish onshore areas. Kristoffersen (1972) has given a biostratigraphic review of the foraminifera in the Miocene deposits. The fauna of the Klintinghoved Formation, there described, shows affinities to the Angulogerina gracilis zone. Some kind of stratigraphic overlap may occur between the two units but more investigations are needed.

The planktonic foraminifera of the Angulogerina gracilis zone are usually rare. Their frequency is seldom more than a few percentage. Most specimens may be referred to Globigerina ex. gr. bulloides.

The regional distribution of the Angulogerina gracilis zone in Denmark (fig. 5) is the widest of all the Oligocene biozones treated in this paper. In addition to its presence in the Northwest and
Central parts of Jutland (Viborg 1 Deep bore and Northwestwards), the zone has been observed from the Mariager Fjord area (Skovbos nye grav), to the East coast of Jutland (from the Aarhus area in North to Middelfart area in the South). From Horsens Fjord and southwards, the zone overlies sediments of Eocene age, even transgressing the Ringkøbing Fyn High. Therefore, it may also probably be present South of the Ringkøbing Fyn High.

As a stratigraphic summary, a correlation chart between the four biozones and the lithological units of the Oligocene deposits is presented in fig. 6. As expected, the figure indicates good agreement between lithostratigraphy and biostratigraphy. The four biozones are each restricted to a lithological unit.

The Turrilina alsatica zone coincides with the Viborg Formation.

The sediments of the Globigerina zone, presented for the first time in this paper, are given the name "Hvorslev Clay". It has probably been described before but because of its high glauconitic content, it has probably been referred to the Grundfør Clay below or the Brejning Clay above.

The Asterigerina gürichi gürichi zone coincides with the Branden Clay Formation in its type locality, the Branden clay pit of Salling. The biozone is assumed to be restricted to this formation.

The Angulogerina gracilis zone is, in Southeast and East Jutland, recognized in the Brejning Clay member of the Vejle Fjord Formation, and in the Ulstrup Clay member of the Sofienlund Formation. It is present in the Mariager Fjord area, as the zone has been observed on the northern side of the fjord (Skovbos nye grav). It is found there in sediments which according to Ravn (1907) and Madsen (1918) can lithologically be correlated with the Cilleborg Clay in its type locality (Cilleborg Clay pit) on the other side of the fjord. However, the 99 specimens of Asterigerina gürichi gürichi from this locality (Troelsen, 1955) cannot exclude the possibility that least part of the Cilleborg Clay also falls within the Asterigerina gürichi gürichi zone. 


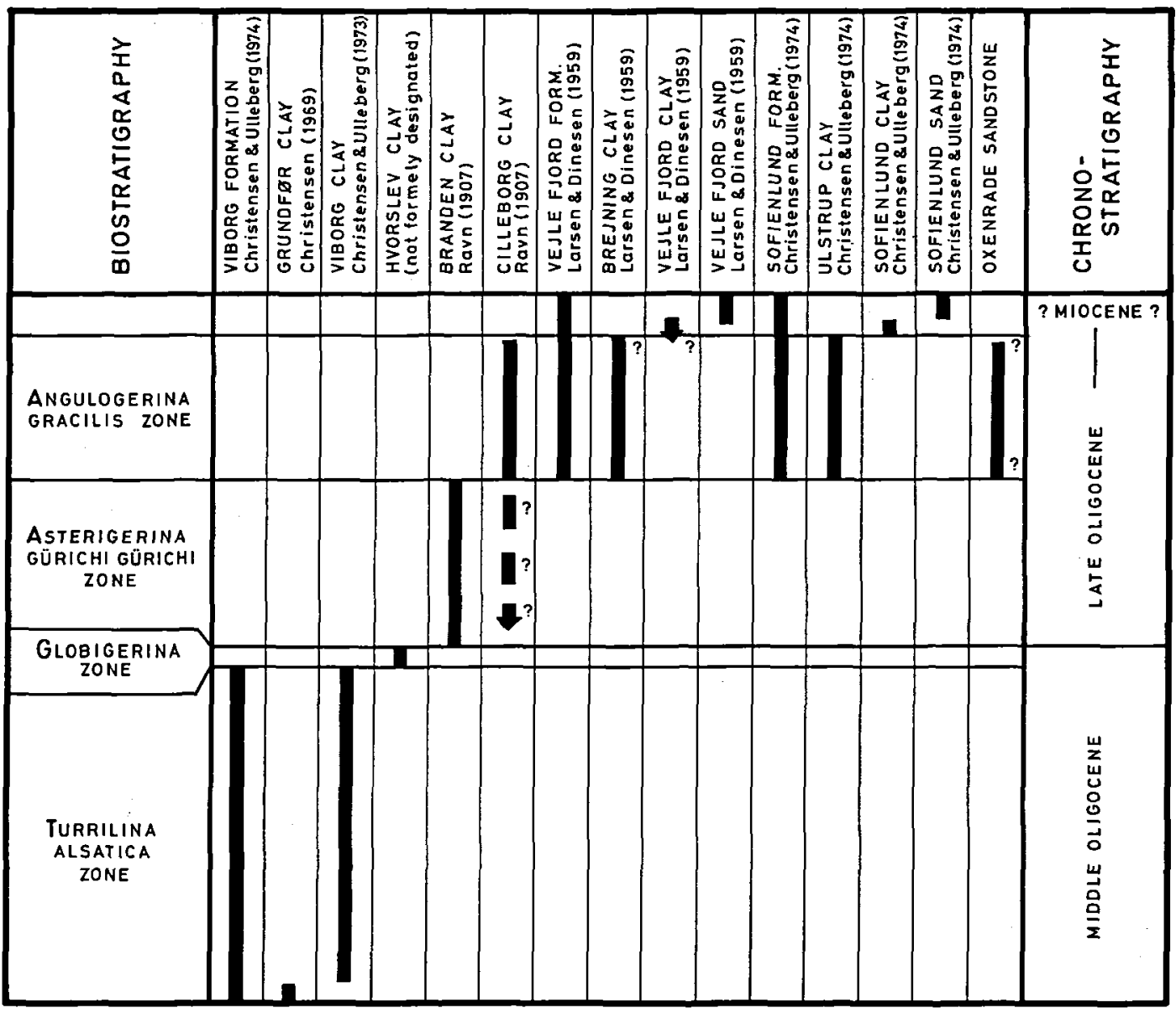

Fig. 6. Oligocene stratigraphy in Denmark. Oligocene lithostratigraphical units and their range in the foraminiferal stratigraphy presented in this paper.

Acknowledgements. The writer wishes to thank the members of the Department of Micropaleontology, Aarhus University who have helped me in many ways to make this study possible. Special thanks due to Dr. philos. R. W. Feyling-Hanssen, who also critically read the manuscript, to Mr. Sven Melgaard who prepared the samples in the laboratory, and to Mrs. Jette G. Nielsen who made the drawings.

Mrs. Bjørg Ruus, Norwegian Petroleum Directorate, Stavanger, prepared some samples in her laboratory.

Special thanks are also given to chief geologist Ame Dinesen Geological Survey of Denmark, who gave me foraminiferal data from the Oligocene section in the Hobro Well no. 1, and to Dr. David Worsley, Saga Petroleum a.s. and Dr. John Peel, Geological Survey of Greenland, for improving the English text.

\section{Dansk sammendrag}

En generel gennemgang af foraminiferfaunaene i de danske oligocæne afsætninger er givet. Stratigrafisk danner faunaene grundlag for inddeling i 4 biozoner, som fra bund til top er: Turrilina alsatica Zonen, Globigerina Zonen, Asterigerina güri- chi gürichi Zonen og Angulogerina gracilis Zonen. De to første zoner refereres til mellem oligocaenet, mens de to sidstnævinte refereres til øvre oligocænet. Zonenes regionale udbredelse i Danmark er præsenteret, samt en sammenstilling af anvendte oligocæne lithologiske navn og deres stratigrafiske udbredelse $i$ den præsenterte foraminiferstratigrafi.

\section{References}

Batjes, D. A. J. 1958: Foraminifera of the Oligocene of Belgium. Koninklijk Belgisch Instituut vor Natuurwetenschappen. Verh. 143, Brüssel, 188 pp.

Bettenstaedt, F., Fahrion, H., Hiltermann, H. and Wick, W. 1962: Tertiär Norddeutschlands. In: Arbeitskreis deutscher Mikropaläontologen: Leitfossilien der Mikropaläontologie. 339-378, Berlin: Borntraeger.

Christensen, L. 1969: Studier over lermineralerne i Vejle Fjord Formationen ved Brejning og Branden Formation i Midtog Nordjylland. Unpubl. prize dissertation. København Universitet. $160 \mathrm{pp}$.

Christensen, L. and Ulleberg, K. 1973: Sedimentology and 
Micropaleontology of the Middle Oligocene sequence at Sofienlund - Denmark. Bull. geol. Soc. Denmark 22, 283305 .

Christensen, L. and Ulleberg, K. 1974: Sediments and foraminifers of the Middle Oligocene Viborg Formation, Denmark. Bull. geol. Soc. Denmark 23, 109-305.

Dam, A. ten and Reinhold, Th. 1942: Die Stratigraphische Gliederung des Niederländischen Oligo-Miozäns nach Foraminiferen. Med. geol. Stichting Ser. C - V - no. 2 .

Dam, T. 1976: Foraminiferer og Stratigrafi $i$ oligocoene aflejringer ved Färup (Mellem Randers og Hobro, Jylland. Bd. 1 og 2. Aarhus University (unpublished thesis).

Doppert, J. W. Chr. \& Neele, N. G. 1983: Biostratigraphy of Marine Paleogene deposits in the Netherlands and adjacent areas. Med. rijks. geol. dienst. 37, no. 2, 79 pp.

Eriksen, K. R. 1937: En foreløbig Meddelelse om Tertiaret ved Brejning paa Sydsiden af Vejle Fjord. Meddr. dansk geol. Foren. 9, 137-150.

Feyling-Hanssen, R. W. 1958: Mikropaleontologiens teknikk. Norges geol. Unders. 203, 35-48.

Harder, P. 1913: De oligocæne Lag i Jærnbanegennemskæringen ved Aarhus Station. Danm. geol. Unders. Rakke 2, $61,172 \mathrm{pp}$.

Hiltermann, H. 1958: Anwendung der Mikropaläontologie in der Geologie, entwickelt durch die Erdölgeologie. In: Freud, H.: Handbuch der Mikroskopie in der Technik, 2,3, 13-60. Frankfurt am Main, Umschau.

Indans, J. 1965: Mikrofaunistisches Normalprofil durch das marine Tertiär der Niederrheinischen Bucht. Geol. Landesamt $N$. rhein-Westf. 1484, 84 pp.

Kristoffersen, K. N. 1965: Foraminiferfaunaen $i$ lagserien $i$ Grundfor Teglvark, med bidrag til placeringen af Eocan' Oligocan gransen i Danmark. Unpublished thesis, Københavns Universitet, $57 \mathrm{pp}$.

Kristoffersen, K. N. 1972: Foraminiferzonering i det jyske Miocæn. Bull. geol. Soc. Denmark, Arsskrift, 25-36.
Kümmerle, E. 1963: Die Foraminiferenfauna des Kasseler Meeressandes (Oberoligozän) im Ahnetal bei Kassel. $A b h$. hess. L. Amt Bodenforsch. 45, 1-72.

Larsen, G. \& Dinesen, A. 1959: Vejle fjord formationen ved Brejning. Sedimenterne og foraminiferfaunaen (oligocanmiocæn). Danmarks geol. Unders. Række 2, 82, 114 pp.

Lieberkind, K. 1977: Summary of the Eocene and Oligocene formations. In: XVth. European Micropaleontological Colloquium, Denmark. 9th - 17th Sept. 1977. 22-27.

Madsen, V. 1918: Om Tertixret ved Mariager Fjord. Danm. geol. Unders. Rakke 4, 1 (8), 41 pp.

Marks, P. \& Vessem, E. J. van, 1971: Foraminifera from the Silberberg Formation (Lower Oligocene) at Silberberg, near Helmstedt. Paläont. Z. 45, 1/2, 53-68.

Meyer, H. 1981: En biostratigrafisk unders $\emptyset$ gelse og palæoф $k o-$ logisk vurdering af Tertiare aflejringer $i$ den vestlige del af Limfjordsområdet baseret på benthoniske foraminiferfaunaers kvalitative og kvantitative sammenscetning. Unpubl. thesis, Aarhus Universitet, bd. I-II, 261 pp.

Mikkelsen, N. 1975: Marine Lower Oligocene sediments in Denmark as indicated by coccoliths in the Viborg Formation. Bull. geol. Soc. Denmark, 24, 83-86.

Ravn, J. P. J. 1907: Molluskfaunaen i Jyllands Tertiæraflejringer. En palæontologisk-stratigrafisk undersøgelse. $K$. dan. Vid. Selsk. Skr., Rakke 7, nat. mat. Afd. 3 (2), 180 pp.

Spiegler, d. 1965: Biostratigraphie des Rupels auf Grund von Foraminiferen im nördlichen Deutschland. Geol. $J b .82$, 447-486.

Troelsen, J. C. 1955: Studies on Ceratobuliminidae (Foraminifera). Medd. Dansk geol. Foren., 12, 448-478.

Ulleberg, K. 1971: En faunistisk-stratigrafisk unders $₫$ kelse av oligocene foraminiferer $i$ Sofienlund, Midt-Jylland. Unpubl. thesis, Aarhus Universitet.

Ulleberg, K. 1974: Foraminifera and stratigraphy of the Viborg Formation in Sofienlund, Denmark. Bull. geol. Soc. Denmark, 23, 269-292. 